\title{
PRODUCTION OF BIO-GAS FROM FLOWERS AND VEGETABLE WASTES USING ANAEROBIC DIGESTION
}

\author{
J Ranjitha', Vijayalakshmi $\mathbf{S}^{\mathbf{2}}$, Vijaya kumar $\mathbf{P}^{\mathbf{3}}$, Nitin Ralph $\mathbf{P}^{4}$ \\ ${ }_{1,2}$ Assistant Professor, $\mathrm{CO}_{2}$ Research and Green technologies Centre, VIT University, Vellore-14 \\ ${ }^{3,4}$ Student, Energy Division, School of Mechanical and Building Sciences, VIT University, Vellore -14.
}

\begin{abstract}
A laboratory study was carried out on anaerobic digestion of vegetable wastes (brinjal, cabbage, carrot, ladies finger) \& flowers (jasmine, sunset flower, Roselle, African wattle, Nile tulip flower, silk tree mimosa.) in a 1 L capacity of anaerobic digestor using cow dung as an inoculums. The digester was operated in the ratio of 1:1 of substrate to inoculums at RT. The substrate concentrations are varied such as 5\%,7\%,10\% was used and amount of gas produced was analyzed using digital pressure gauge. The Results obtained showed that flowers had given higher yield of biogas than vegetable wastes and the digestion period was less. The average biogas production potential of withered flowers was observed as $16.69 \mathrm{~g} / \mathrm{kg}$ in $4.5 \mathrm{days}$, where in case of vegetable wastes it was $9.089 \mathrm{~g} / \mathrm{kgS}$ in 6 days. The study showed that flowers which are available in abundant in India is thrown away after 1 (or) 2 days use causing nuisance to the environment. It is seen it is a very good feed stock for biogas production. Generation of biogas from flowers upholds the concept of waste to wealth in enhancing sustainability of development. Future research work is mainly focused on the characterization of Bio-gas using sophisticated instruments.
\end{abstract}

Keywords: Biogas, anaerobic digestion, vegetable waste, flower, substrate, Inoculums $* * *$

\section{INTRODUCTION}

Anaerobic digestion is a bio-chemical technology used for the treatment of organic wastes and the production of biogas, which can be used as a fuel for heating or cogeneration of electricity and heat [1]. Bio-gas has globally remained a renewable energy source derived from plants that use solar energy during the process of photosynthesis. Being a source of renewable natural gas, it has been adopted as one of the best alternatives for fossil fuels after 1970's world energy crisis. Bio-gas is a colourless, flammable gas produced via anaerobic digestion of animal, plant, human, industrial and municipal wastes amongst others, to give mainly methane (50-70\%), carbon dioxide (20-40\%) and traces of other gases such as nitrogen, hydrogen, ammonia, hydrogen sulphide, water vapour etc. [2]. Bio-gas production is mainly based on the bio-chemical process.

$$
\begin{gathered}
\left(\mathrm{C}_{6} \mathrm{H}_{10} \mathrm{O}_{5}\right) \mathrm{n}+\mathrm{nH}_{2} \mathrm{O} \longrightarrow \mathrm{n}\left(\mathrm{C}_{6} \mathrm{H}_{12} \mathrm{O}_{6}\right)-\text { Hydrolysis } \\
\mathrm{n}\left(\mathrm{C}_{6} \mathrm{H}_{12} \mathrm{O}_{6}\right) \longrightarrow \mathrm{n} \mathrm{CH}_{3} \mathrm{COOH} \text {-Acetogenesis } \\
3 \mathrm{nCH}_{3} \mathrm{COOH} \longrightarrow \mathrm{n} \mathrm{CH}_{4}+\mathrm{CO}_{2}-\text { Methanogenesis }
\end{gathered}
$$

The effluent of this process is a residue rich in essential inorganic elements like nitrogen and phosphorus needed for healthy plant growth known as bio fertilizer which when applied to the soil enriches it with no detrimental effects on the environment [3]. There are various types of waste materials available from different sources, but not all waste materials are biodegradable. Only biodegradable waste materials can produce biogas. Again, the biogas generation capacity is not the same for all biodegradable waste materials .The content of biogas varies with the material being decomposed and the environmental conditions involved. Potentially, all organic waste materials contain adequate quantities of the nutrients essential for the growth and metabolism of the anaerobic bacteria in biogas production. However, the chemical composition and biological availability of the nutrients contained in these materials vary with species, factors affecting growth and age of the animal or plant [4].

Various wastes have been utilized for biogas production and they include amongst others; animal wastes [5, 6, 7], industrial wastes [8], food processing wastes [9], plant residues [10, 11] etc. Many other wastes are still being researched on as potential feedstock for biogas production. Withered flowers and vegetable wastes are being considered as a potential feed stock. Withered flowers are easily available in gardens, streets, flower markets etc., where vegetable wastes are available in mess, hotels etc. A full study was undertaken to investigate the biogas production potentials and capabilities of flowers and vegetable waste in terms of biogas yield and effective time period [12-14]. The study revealed that withered flowers had a high yield of biogas than vegetable wastes with in less digestion period. 

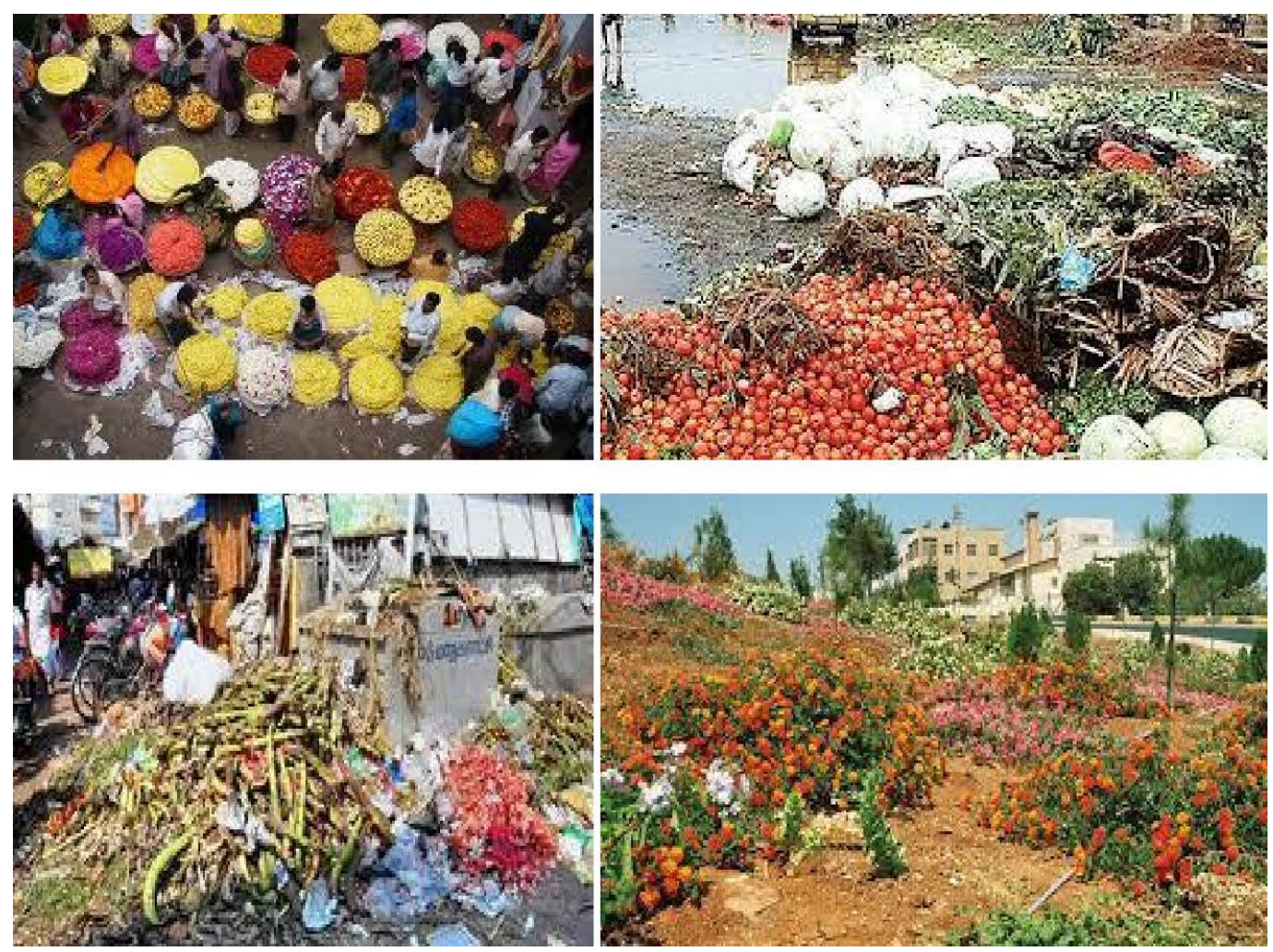

\section{MATERIALS AND METHODS}

\subsection{Substrate and Inoculum}

Vegetable wastes and Flower wastes were collected from Vellore District of Tamilnadu.

Table 1: Represents the Vegetable wastes collected from Vellore District of TN State.

\begin{tabular}{|l|l|}
\hline $\begin{array}{l}\text { COMMON } \\
\text { NAME }\end{array}$ & $\begin{array}{l}\text { SCIENTIFIC } \\
\text { NAME }\end{array}$ \\
\hline 1.Brinjal & Solanum melongena \\
\hline 2.Cabbage & Brassica oleracea \\
\hline 3.Ladies finger & $\begin{array}{l}\text { Abelmoschus } \\
\text { esculentus }\end{array}$ \\
\hline 4.Carrot & Daucus carota \\
\hline
\end{tabular}

Table 2: Represents the Flower and Vegetable wastes collected from Vellore District of TN State.

\begin{tabular}{|l|l|}
\hline COMMON NAME & \multicolumn{1}{|c|}{ SCIENTIFIC NAME } \\
\hline 1.Jasmine & Jasminum grandiflorum \\
\hline 2.Sunset flower & Chrysanthemum indicum \\
\hline 3.Roselle & Hibiscus sabdariffa \\
\hline 4.African wattle & Peltophorum africanum \\
\hline 5.Nile tulip tree & Markhamia lutea \\
\hline 6.Silk mimosa tree & Albuzia julibrissin \\
\hline
\end{tabular}

Feedstock was prepared by drying the wastes in hot air oven at $105^{\circ} \mathrm{C}$ until moisture content appeared to be 0 . After drying the wastes were grinded into fine powder. Cow dung used as inoculum was collected from VIT dairy farm. Fresh cow dung was mixed with water at 1:1 ratio and filtered.

\subsection{Anaerobic Digestor:}

operated at a room temperature varying from 26 to $36{ }^{\circ} \mathrm{C}$. Three different feedstock concentration $(5 \%, 7 \%, 10 \%)$ was prepared .Anaerobic digestor was filled up to $300 \mathrm{ml}$ with feedstock and inoculums (1:1) leaving $700 \mathrm{ml}$ free space for gas production. Then the digester was purged with nitrogen gas for $5 \mathrm{~min}$ to assure anaerobic condition before it was tightly closed with a rubber stopper

\subsection{Digital Pressure Gauge:}

The amount of biogas produced in the anaerobic digestor was analysed by the Digital Pressure Gauge by checking the pressure of biogas in the digestor for every 24 hours.

\subsection{Statistical Analysis:}

Observed daily biogas production is calculated using STP condition. STP refers to $273.15 \mathrm{~K}$ and $1 \mathrm{~atm}$ pressure.

$$
\mathrm{P}_{\mathrm{o}} \mathrm{V}_{\mathrm{o}} \mathrm{T} / \mathrm{P} \mathrm{V} \mathrm{T} \mathrm{T}_{\mathrm{o}}=\mathrm{n} / \mathrm{n}_{1}
$$

Po $=$ standard pressure

$\mathrm{P}=$ pressure of biogas observed

$\mathrm{Vo}=$ volume of 1 mole gas at $\operatorname{STP}(22.4141) \mathrm{V}=$ volume of gas collected $(700 \mathrm{ml})$.

To $=$ standard temperature.

$\mathrm{T}=$ room temperature $(26-$

$\left.36^{0} \mathrm{C}\right) \mathrm{n}=1$ mole.

$\mathrm{n} 1=$ moles of gas.

Weight of biogas produced is determined by calculating the average molecular weight of bio gas from its composition. Avg. $\mathrm{MW}=\mathrm{CH}_{4}$ composition

$* \mathrm{MW}$ of $\mathrm{CH}_{4}+\mathrm{CO}_{2}$ composition $* \mathrm{MW}$ of $\mathrm{CO}_{2}$

Experiments are carried out in a $1 \mathrm{~L}$ batch-type reactor 
Avg. $\mathrm{MW}=16 * \mathrm{CH}_{4}$ composition $+44 * \mathrm{CO}_{2}$ composition/100 Weight of biogas $=$ Avg. $\mathrm{MW}^{*}$ moles of biogas.

Weight of biogas calculated is the amount of biogas produced in the tank. The amount of biogas produced per $\mathrm{kg}$ of substrate was calculated. The biogas produced per $\mathrm{kg}$ of dried substrate was calculated first and from the moisture content of each substrate, the biogas produced per $\mathrm{kg}$ of original substrate was calculated using standard formula.

\section{RESULTS AND DISCUSSION}

\subsection{Moisture Content:}

Moisture content of most of the substrates vary between $80 \%-90 \%$.Sunset flower has the maximum moisture content of $91 \%$. Silk tree mimosa $(47.27 \%)$ and African wattle $(69 \%)$ has lesser moisture content among these substrates shown in the Table 3.

Table 3 Represents the $\%$ of Moisture Content present in the vegetable and Flower wastes

\begin{tabular}{|l|l|l|l|}
\hline SUBSTRATE & $\begin{array}{l}\text { INITIAL } \\
\text { WEIGHT }\end{array}$ & $\begin{array}{l}\text { FINAL } \\
\text { WEIGHT }\end{array}$ & $\begin{array}{l}\text { MOISTURE } \\
\text { CONTENT }\end{array}$ \\
\hline BRINJAL & $1.134 \mathrm{~kg}$ & $0.216 \mathrm{~kg}$ & $80.95 \%$ \\
\hline CABBAGE & $1.084 \mathrm{~kg}$ & $0.104 \mathrm{~kg}$ & $90.40 \%$ \\
\hline LADIES FINGER & $1.486 \mathrm{~kg}$ & $0.168 \mathrm{~kg}$ & $88.69 \%$ \\
\hline CARROT & $0.830 \mathrm{~kg}$ & $0.110 \mathrm{~kg}$ & $86.74 \%$ \\
\hline JASMINE & $0.474 \mathrm{~kg}$ & $0.092 \mathrm{~kg}$ & $80.59 \%$ \\
\hline SUNSET FLOWER & $0.584 \mathrm{~kg}$ & $0.052 \mathrm{~kg}$ & $91 \%$ \\
\hline NILE TULIP FLOWER & $0.242 \mathrm{~kg}$ & $0.038 \mathrm{~kg}$ & $84.29 \%$ \\
\hline SILK TREE MIMOSA & $0.110 \mathrm{~kg}$ & $0.058 \mathrm{~kg}$ & $47.27 \%$ \\
\hline ROSELLE & $0.185 \mathrm{~kg}$ & $0.028 \mathrm{~kg}$ & $84.85 \%$ \\
\hline AFRICAN WATTLE & $0.106 \mathrm{~kg}$ & $0.034 \mathrm{~kg}$ & $69 \%$ \\
\hline
\end{tabular}

\subsection{Production of Biogas:}

The table 4 shows the amount of biogas produced and amount of biogas produced per $\mathrm{kg}$ of substrate for different concentrations of substrate in slurry.

Table 4 Represents the production of biogas from vegetable and Flower wastes

\begin{tabular}{|l|c|c|c|c|c|c|}
\hline \multicolumn{1}{|c|}{ SUBSTRATE } & $\mathbf{5 \%}$ Amt. of gas & $\begin{array}{c}\text { Amt of. } \\
\text { gas/kg } \\
\text { substrate }\end{array}$ & $\mathbf{7 \%}$ Amt. of gas & $\begin{array}{c}\text { Amt of. } \\
\text { gas/kg } \\
\text { substrate }\end{array}$ & $\begin{array}{c}\mathbf{1 0 \%} \text { Amt. of } \\
\text { gas }\end{array}$ & $\begin{array}{c}\text { Amt of. } \\
\text { gas/kg } \\
\text { substrate }\end{array}$ \\
\hline AFRICAN WATTLE & $0.49918 \mathrm{~g}$ & $20.63 \mathrm{~g}$ & $0.55791 \mathrm{~g}$ & $16.47 \mathrm{~g}$ & $0.52855 \mathrm{~g}$ & $10.92 \mathrm{~g}$ \\
\hline ROSELLE & $0.51387 \mathrm{~g}$ & $10.37 \mathrm{~g}$ & $0.57259 \mathrm{~g}$ & $8.26 \mathrm{~g}$ & $0.51387 \mathrm{~g}$ & $5.18 \mathrm{~g}$ \\
\hline CABBAGE & $0.46982 \mathrm{~g}$ & $6.01 \mathrm{~g}$ & $0.57259 \mathrm{~g}$ & $5.23 \mathrm{~g}$ & $0.51387 \mathrm{~g}$ & $3.28 \mathrm{~g}$ \\
\hline BRINJAL & $0.45514 \mathrm{~g}$ & $11.55 \mathrm{~g}$ & $0.69005 \mathrm{~g}$ & $12.51 \mathrm{~g}$ & $0.55791 \mathrm{~g}$ & $7.08 \mathrm{~g}$ \\
\hline CARROT & $0.49918 \mathrm{~g}$ & $8.824 \mathrm{~g}$ & $0.58728 \mathrm{~g}$ & $7.41 \mathrm{~g}$ & $0.42577 \mathrm{~g}$ & $3.76 \mathrm{~g}$ \\
\hline LADIES FINGER & $0.55791 \mathrm{~g}$ & $8.412 \mathrm{~g}$ & $0.646 \mathrm{~g}$ & $6.95 \mathrm{~g}$ & $0.52855 \mathrm{~g}$ & $3.98 \mathrm{~g}$ \\
\hline NILE TULIP FLOWER & $0.57259 \mathrm{~g}$ & $11.99 \mathrm{~g}$ & $0.60196 \mathrm{~g}$ & $9.004 \mathrm{~g}$ & $0.51387 \mathrm{~g}$ & $5.38 \mathrm{~g}$ \\
\hline SILK TREE MIMOSA & $0.58728 \mathrm{~g}$ & $41.28 \mathrm{~g}$ & $0.63132 \mathrm{~g}$ & $31.70 \mathrm{~g}$ & $0.67537 \mathrm{~g}$ & $23.73 \mathrm{~g}$ \\
\hline SUNSET FLOWER & $0.44046 \mathrm{~g}$ & $5.28 \mathrm{~g}$ & $0.52855 \mathrm{~g}$ & $4.52 \mathrm{~g}$ & $0.45514 \mathrm{~g}$ & $2.73 \mathrm{~g}$ \\
\hline JASMINE & $0.41109 \mathrm{~g}$ & $10.63 \mathrm{~g}$ & $0.36705 \mathrm{~g}$ & $6.78 \mathrm{~g}$ & $0.46982 \mathrm{~g}$ & $6.07 \mathrm{~g}$ \\
\hline
\end{tabular}




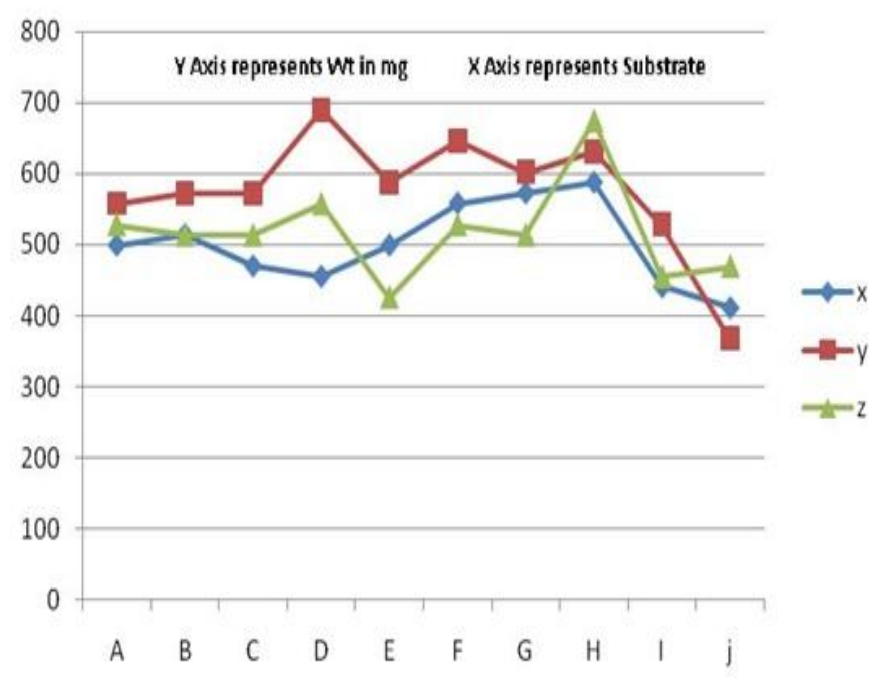

A-African wattle, B-roselle, C-Cabbage, D-Brinjal, E-Carrot, F-Ladies finger, G-Nile tulip tree, $\mathrm{H}$-Silk tree mimosa, I-

Sunset flower, J-Jasmine. $\mathrm{x}-5 \%, \mathrm{y}-7 \%, \mathrm{z}-10 \%$

Fig 1: Graph showing production of biogas from different substrates

The above graph shows the amount of biogas produced by the digestion in the anaerobic tank. This shows that the production of biogas is more in $7 \%$ for most of the substrates, followed by $5 \%$ and $10 \%$. This shows that $7 \%$ substrate is more efficient in producing biogas. More biogas production is seen in case of flowers and brinjal.

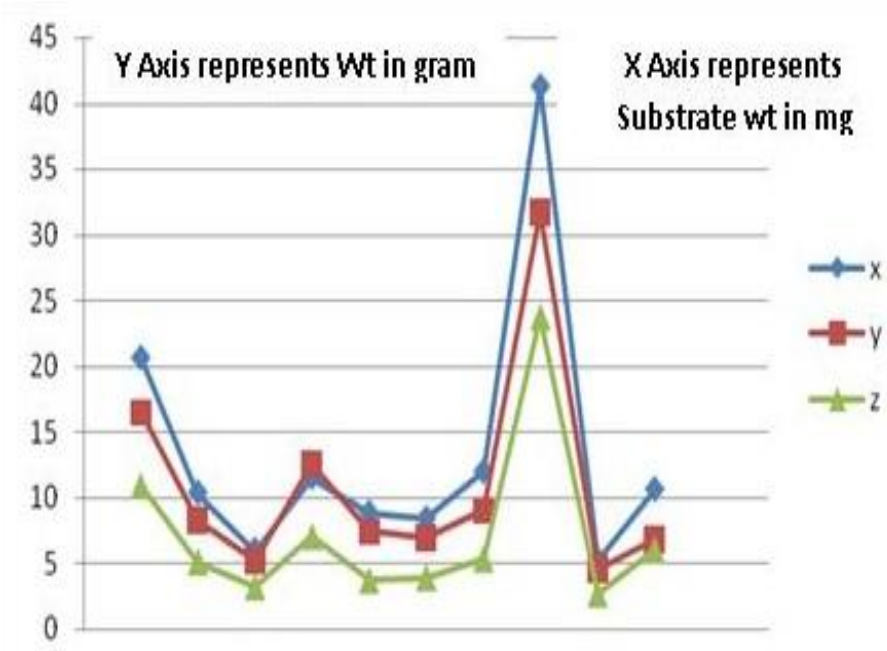

A-African wattle, B-roselle, C-Cabbage, D-Brinjal, ECarrot, F-Ladies finger, G-Nile tulip tree, H-Silk tree mimosa, I-Sunset flower, J-Jasmine. X-5\%,y-7\%,z-10\%

Fig 2: Graph showing production of biogas per kg substrate from different substrates

The above graph shows the amount of biogas produced per $\mathrm{kg}$ substrate. The peaks in the graph are amount of biogas per $\mathrm{kg}$ substrate of African wattle and silk tree mimosa. Among vegetable wastes brinjal produced more amount of biogas.
Table 5: shows the production rate of Jasmine increases day by day.

\begin{tabular}{|c|r|r|r|}
\hline DAYS & \multicolumn{5}{|c|}{$\mathbf{5 \%}$} & \multicolumn{1}{|l|}{$\mathbf{7 \%}$} & \multicolumn{1}{l|}{$\mathbf{1 0 \%}$} \\
\hline INITIAL & \multicolumn{1}{|c|}{$\mathbf{0}$} & $\mathbf{0}$ & $\mathbf{0}$ \\
\hline $\mathbf{1}$ & $\mathbf{2 2 0 . 2 3}$ & $\mathbf{1 4 6 . 8 2}$ & $\mathbf{3 6 7 . 0 5}$ \\
\hline 2 & $\mathbf{2 9 3 . 6 4}$ & $\mathbf{2 7 8 . 9 5}$ & $\mathbf{4 5 5 . 1 4}$ \\
\hline $\mathbf{3}$ & $\mathbf{3 3 7 . 6 8}$ & $\mathbf{3 0 8 . 3 2}$ & $\mathbf{4 6 9 . 8 2}$ \\
\hline 4 & $\mathbf{3 8 1 . 7 3}$ & $\mathbf{3 5 2 . 3 6}$ & $\mathbf{4 6 9 . 8 2}$ \\
\hline $\mathbf{5}$ & $\mathbf{4 1 1 . 0 9}$ & $\mathbf{3 6 7 . 0 5}$ & $\mathbf{4 6 9 . 8 2}$ \\
\hline $\mathbf{6}$ & $\mathbf{4 1 1 . 0 9}$ & $\mathbf{3 6 7 . 0 5}$ & $\mathbf{4 6 9 . 8 2}$ \\
\hline
\end{tabular}

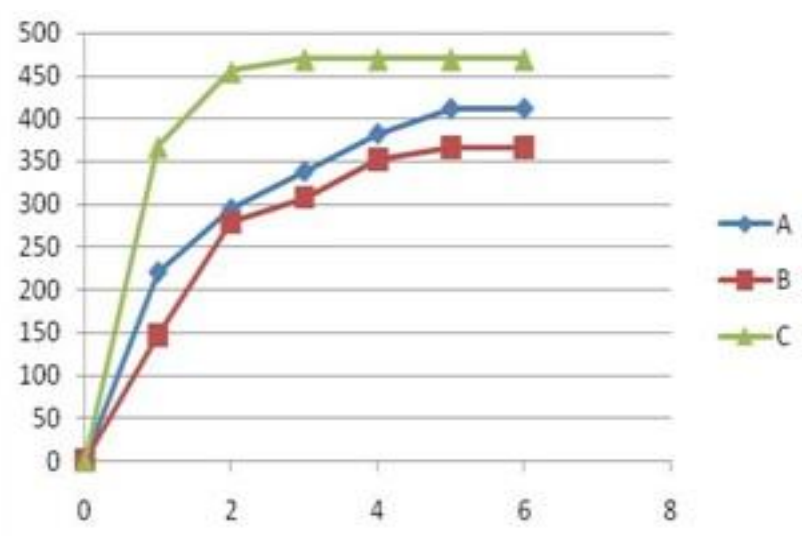

Fig 3: shows the production rate of Jasmine increases day by day $\mathrm{Y}$-axis - wt in $\mathrm{mg}$ and $\mathrm{X}$-axis - days

Digestion period: The digestion period of substrates varies from 4-6 days. Flowers like Sunset flower, silk tree mimosa, Nile tulip flower produced gas in 4 days. African wattle, Roselle took 5 days and vegetable wastes produced gas in 6days time. Flowers produced more amount of biogas at faster rate.

\section{CONCLUSIONS}

The study has shown that flowers had a faster rate of biogas production and higher production per unit weight of the substrate than vegetable waste. Flowers which are available in abundant in India including the immediate environment is a very good feedstock for biogas production. This waste can be utilized for energy generation instead of having them littered around and invariably constituting a nuisance to the environment. These cause problem to the people , authorities as well. Many flowers are being used for decorating functions, etc. After used they are being wasted. They can be used for biogas production as flowers give high yields of biogas and at faster rate.

\section{ACKNOWLEDGEMENTS}

We thankful for VIT Management for giving constant support and encouragement throughout our research work.

\section{REFERENCES}

[1]. Owen. W. F. Energ.r in Waste Water Trenrmenr. Prentice-Hall. India, 1982. pp. 2125

[2]. Maishanu SM, Musa M and Sambo AS, 1990, Nigerian Journal of Solar Energy, 9: 183-194.

[3]. Bhat P.R., Chanakya H.N. and Ravindranath N.H., 2001, J. Energy Sustainable Dev. 1:39 - 41 
[4]. Anunputtikul W and Rodtong S, 2004, The Joint International Conference on -Sustainable Energy and Environmental (SEE)\|, Hua Hin, Thailand. 1-3 Dec, 2004, 238- 243

[5]. Nwagbo EE, Dioha IJ, Gulma MA, 1991, Nig. J. Solar Energy. 10: 145 - 149.

[6]. Zuru A.A., Saidu H., Odum E. A. and Onuorah O.A. 1998, Nig. J. Renewable Energy. 6 (1\&2): 43 - 47.

[7]. Alvarez R, Villica R and Liden G 2006, Biomass and Bioenergy. 30: 66-75.

[8]. Uzodinma EO, Ofoefule AU, Eze JI. and Onwuka ND, 2007, Trends Appl. Sci. Res. 2 (6): 554-558.

[9]. Arvanitoyannis I.S. and Varzakas T.H. 2008, Crit. Rev. Food Sci. Nut. 48 (3): 205-247.

[10]. Ofoefule AU and Uzodinma EO, 2008, Niger. J. Solar Energy. 19: $57-62$.

[11]. Ofoefule AU, Uzodinma EO and Onukwuli OD, 2009, Int. J. Phy. Sci. 4(8): 535-539.

[12]. Guanaseelan, V.N., 2004. Biochemical methane potential of fruits and vegetable solid waste feedstocks. Biomass and Bioenergy 26, 389-399.

[13]. Misi, S.N., Forster, C.F., 2001. Batch co-digestion of multi-component agro-wastes. Bioresource Technology 80 (1), 19-28.

[14].Zhang, R.H., El-Mashad, H.M., Hartman, K., Wang, F., Liu, G., Choate, C., Gamble, P., 2007. Characterization of food waste as feedstock for anaerobic digestion. Bioresource Technology 98 (4), 929-935. 